\title{
القيم الشعرية في شعر زمرك (دراسة فنية)
}

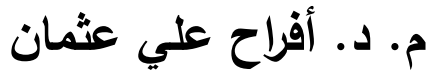

جامعة بغداد/ كلية اللغات

الماخص:

لقد طبع الله تعالى النفس الانسانية على حبّ الجمال، والتغني به أينما وجد فهي فطرة إنسانية عند جميع البشر، فتطرب الأذن لسماع كلٍ جميل كما ويعشق القلب كل جميل وانطلاقاً من ذلك كان بحثنا بعنوان ((القيم الجمالية في شعر ابن زمرك)) دراسة فنية، وقد تطلب ذلك تقسيم البحث على مبحثين، تقدمهما تمهيداً مقسماً على بعلى فقرتين، كانت إحداهما في بيان مفهوم القيمة والجمال، أما الأخرى؛ فكانت إضاءة بسيطة لحياة ابن زمرك إذ لابدًّ من معرفة سطور عن حياته قبل البدء بقراءة شعره، أما المبحث الأول؛ فكان في بيان القيم الجمالية في ديوانه مقسماً على ثلاث نقاط الأولى في جمال الحبيبة، والثانية في جمال الممدوح أو نفس المددوح، والثالثة في جمال الوطن، وجاء المبحث الثاني للدراسة الفنية مقسماً على ثلاث نقاط أيضاً، كانت الأولى في دراسة بعض أساليب

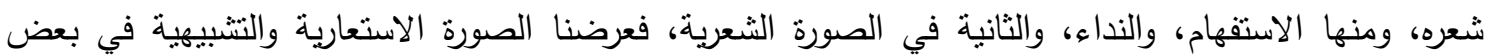

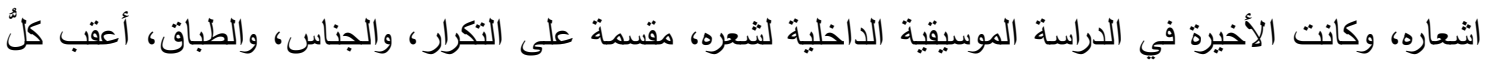
ذللك خاتمة تضمنت أهم النتائج، ثم قائمة بالمصادر والمراجع.

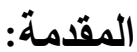

لقد تحدث الناس قديماً عن الجمال والقيمة، ولكل منهما مصطلحاً ومعانٍ، وقد ارتأينا في هذا البحث دمج المصطلحين ليكونا عنواناً واحداً، وهو القيم الجمالية.

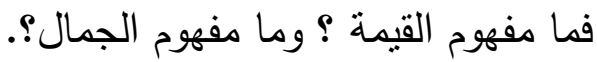

1- مفهوم القيمة: وهي ثن الثيء بالتقويم، نقول: تقاموا فيما بينهم (1) هكذا عرّفها ابن منظور (ت II (Vه). أو هي قدر الثيء واستواؤه (Y). أما في الاصطلاح فهي : أساس ما يسمى بالحكم التقويميّ، أي ذلك الحكم الذي يمنح المدح أو الذم لصفات يراها المصدّر للحكم في المفاضلة بين شيئين أو أكثر(ع)، وبذلك نرى أنَّ معناها الاصطلاحيّ لا يخرج كثيراً عن معناها اللغويّ.

والقيم صنفان: (( صنف يلتمس لذاته، وبطلب كفايته ويكون مطلقاً لا يحده زمان ومكان، وصنف نسبي ينشده الناس كوسيلة لتحقيق غاية لهذا يختلف باختلاف حاجات الناس ومطالبهم)(0) 
r- مفهوم الجمال: ولو عرفنا لفظة الجمال وأخذنا مادة (ج ، م ، ل) كما وردت في أساس

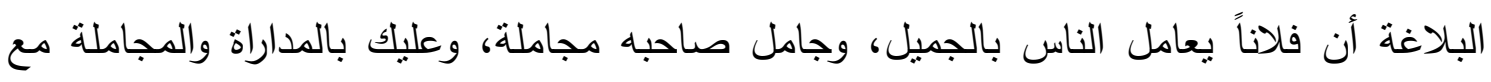

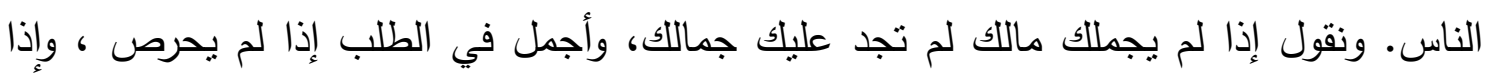

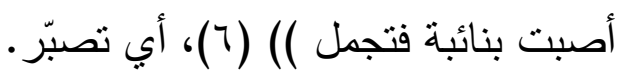

ولابن منظور رأي في الجمال قائلاً فيه: هو ((الحسن في الخلق والخُلق وهو الاتثئد

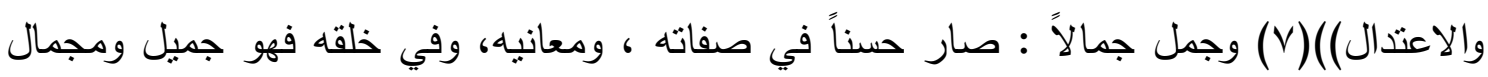

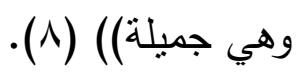

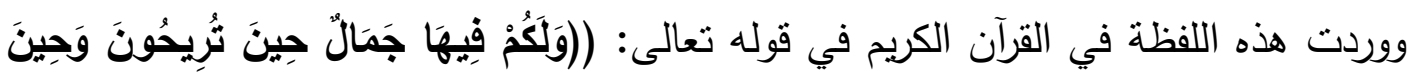

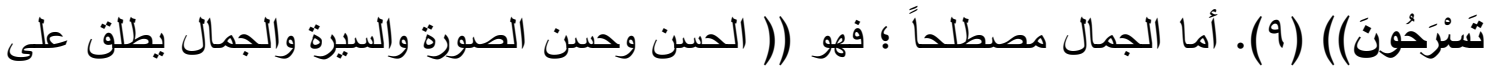
معنيين : أحدهما الجمال الذي يعرفه الجمهور مثل صفاء اللون ولين الملمس وغير ذلكان ، وثنانيهما

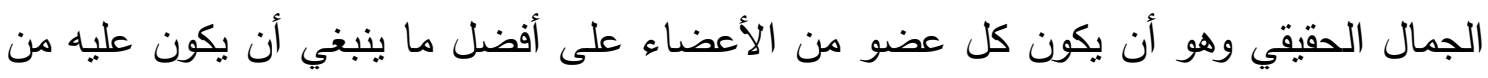

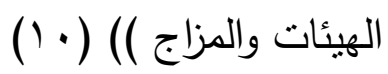
كما يتضح مفهوم الجمال من وجهة نظر الفلاسفة منذ القدم ، فقد أثنار افتتان الناس على مر الفر

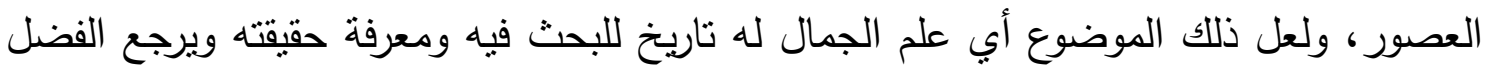

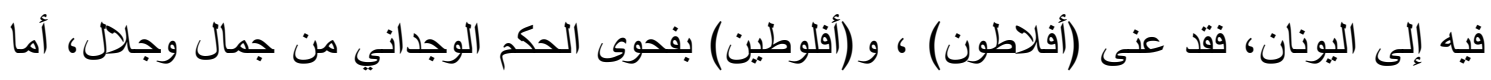
(أرسطو) فقد اهتم بوضع نظرية في طبيعة الفن.

وكان الفيلسوف الألماني (كريستيان ولف) قد قسم قوى الادراك إلى عليا علمها المنطق الذي

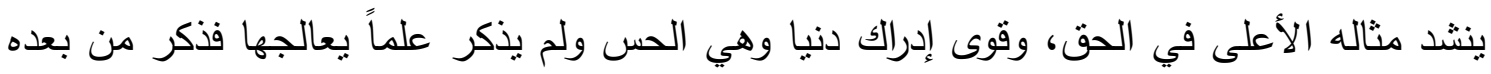

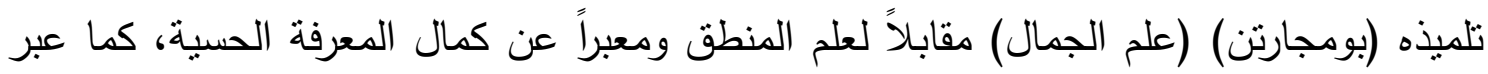
المنطق عن كمال المعرفة العقلية، وكان (بومجارتن) اول من استخدم علم الجمال بمعنى فلسفة الجميل وتابعه في ذلك العمل على استقلال ذلك العلم تلميذه (ماير) وغيره من المحدثين.

وقد شهد القرن الثامن عشر في انكلترا تقدماً ملحوظاً في ذلك وقد ساهم في ذلك (ثافتسبري) وفي اسكتلندا (برك، وهوم) في ألمانيا، وكانط الذي يعد المؤسس الحقيقي لعلم الجمال في صورته

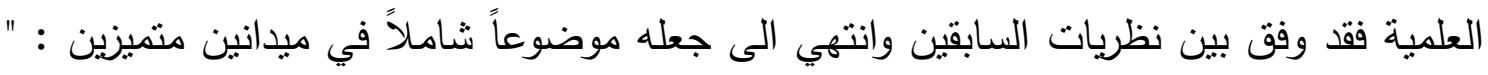

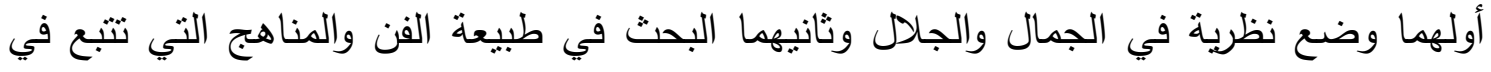
تصنيف الفنون الجميلة"(1)، (1)، واستمر بعد (كانط) (هيجل) وأتباعه وهكذا ، وعند (جون هربارت)

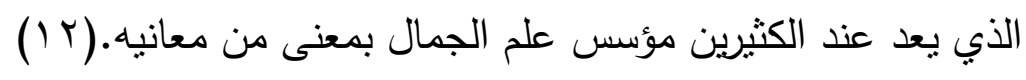


هو أبو عبداله محمد بن يوسف بن محمد بن أحمد بن يوسف بن محمد الصريحيّ القريضيّ

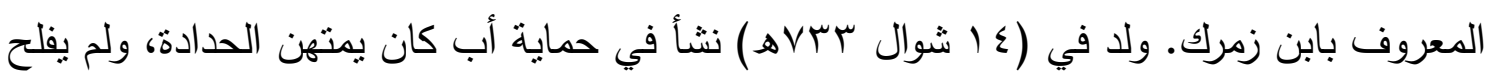

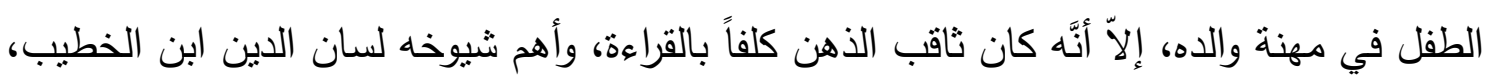

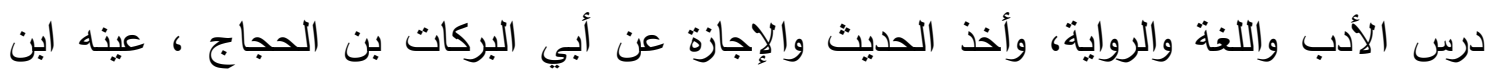

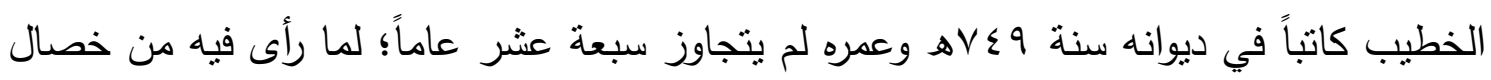
حميدة عنده فقضى مدة طويلة في خدمة الغني باله، وكانت حافلة بالأحداث السياسية الداخلية

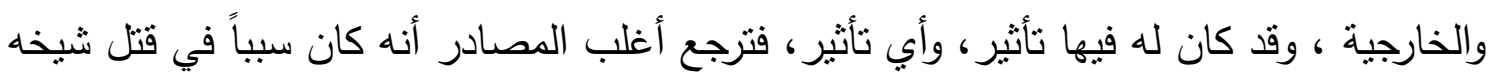

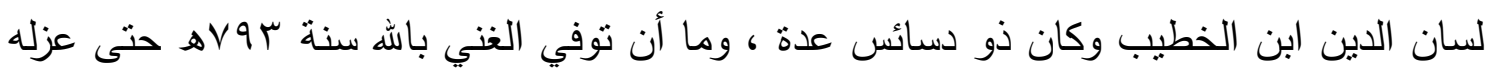

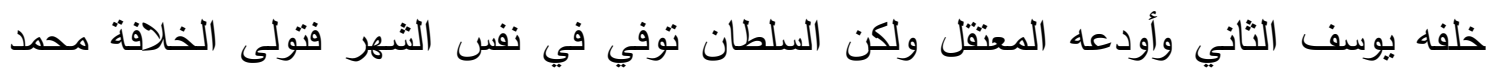
السابع فعزله وعين الفقبه ابن عاصم فكانت نهايته على يد محمد السابع بسبب كثرة مكائده فأوعز لبعض أعوانه بالقضاء عليه فهلك في جنح الليل في جوف داره على يد مخدومه [هو السلطان

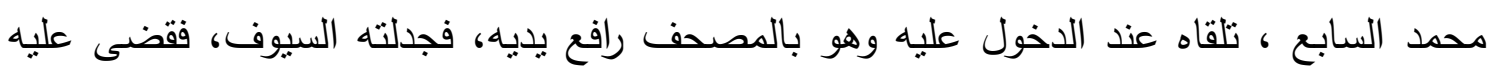

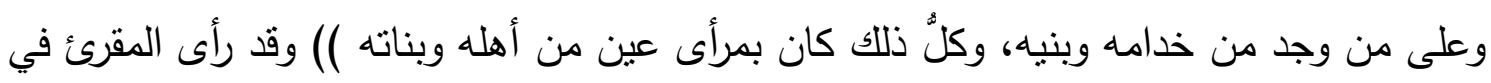

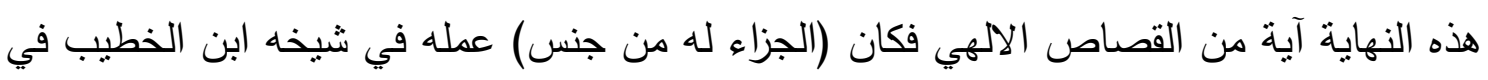

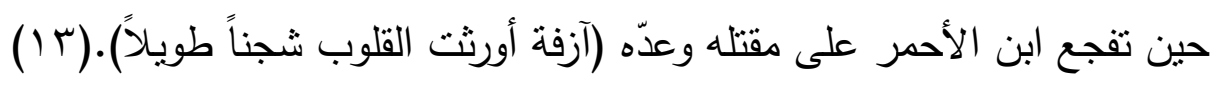

\section{أنماط القيم الجمالية:}

1- جمال الحبيبة: لقد تغنّى الثُعراء على مرَّ الزمان ، بجمال المحبوبة يعينهم على ذلك جمالها

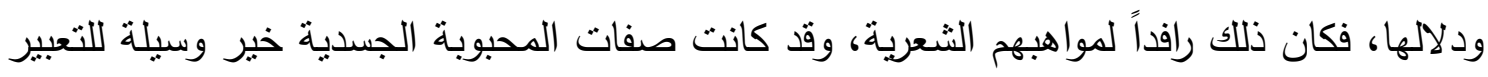

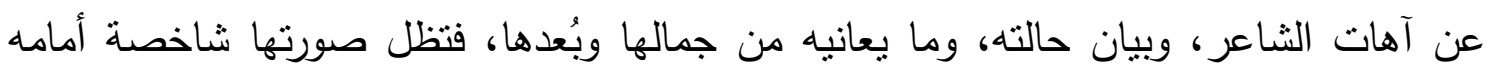

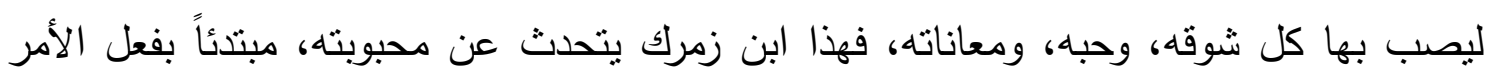

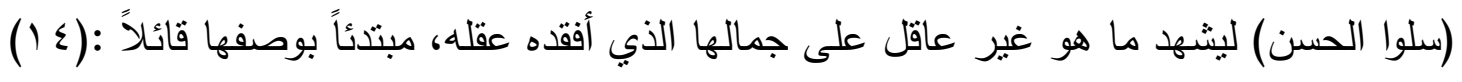
سلوا الحسنُ عنه إذ أسال عوارضاً ضواحكه حب الغمام وبرقها وريقته خمرُ فمن عُلَّ كاسها

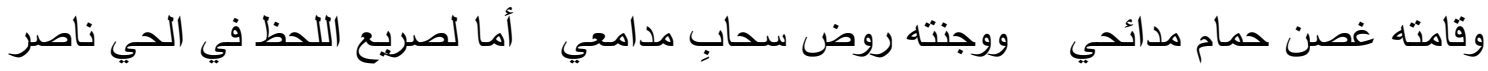

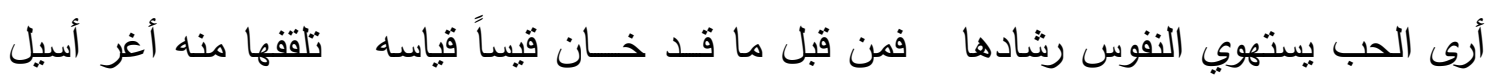

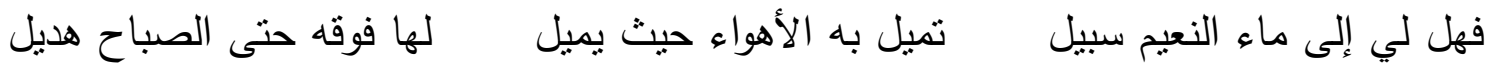

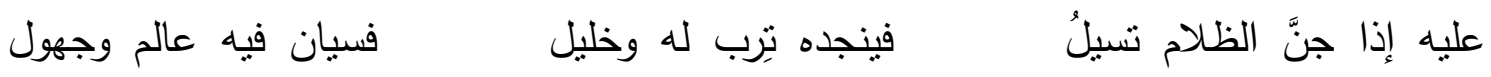

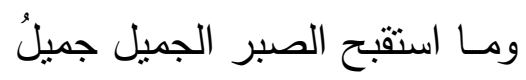


وييقى جمالها يمده بأعذب الألحان، فيتغنى بحسنها، وجمالها، مظهراً قيم الجمال فيها

قائلاً: (10)

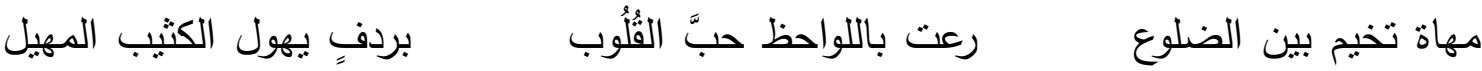

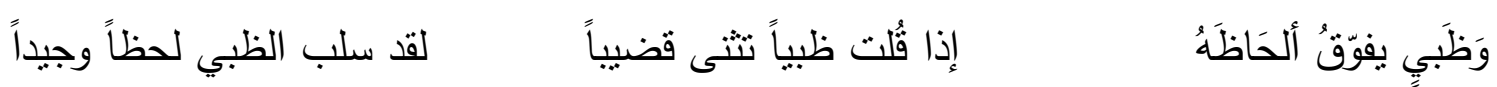

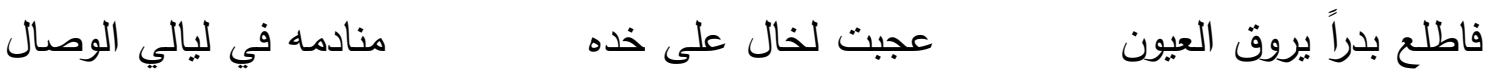

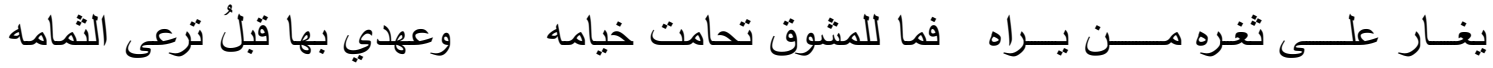

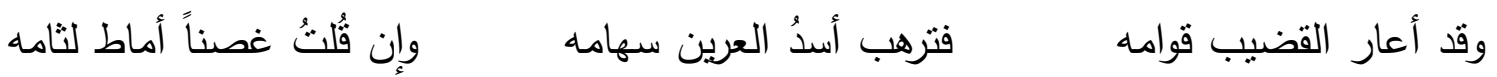

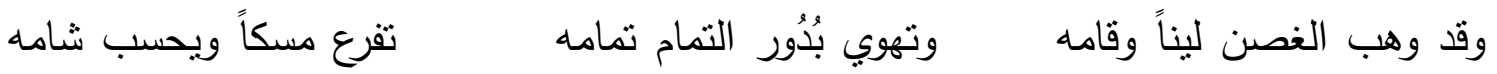

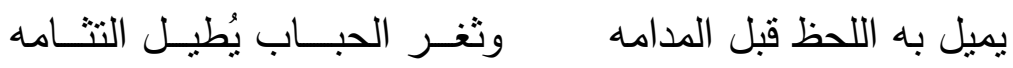

وعلى عادة الثعراء بذكر صفات المحبوبة، يذكر ابن زمرك صفات محبوبته مظهراً مواطن

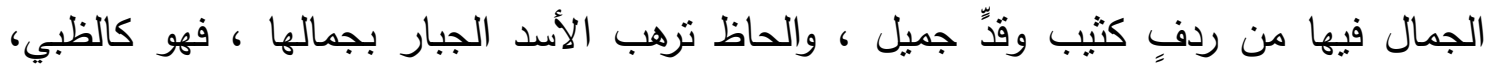

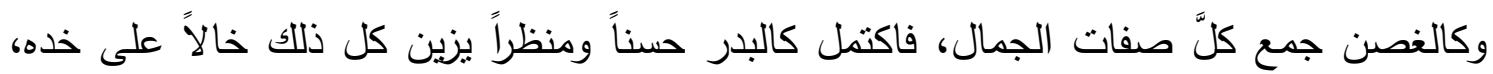
فيزيده شوقاً وناراً؛ لبسعفه من يقول له في غفله إلاّ أنّ عفافه يمنعه من ذللك، ويظهر قيمة وليمة الجمال

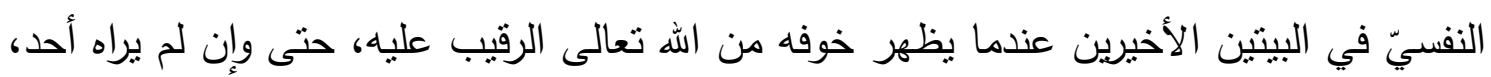

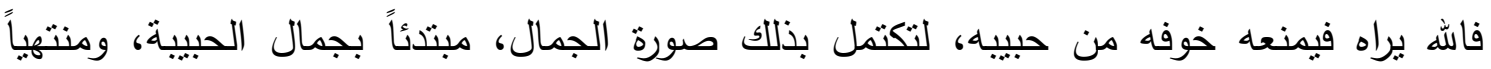

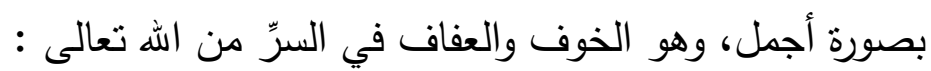

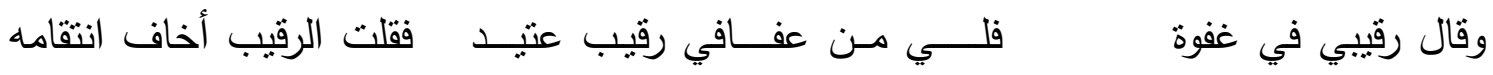

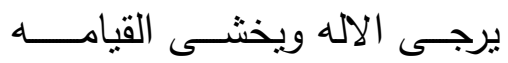

ץ- جمال الممدوح: لصفات الممدوح عند ابن زمرك ثروة شعرية بما يملكه ممدوحه من صفات الكرم ، والثجاعة ، والبسالة ، والأخلاق الرفيعة ، وسماحة النفس التي كونت له له معجماً شعرياً ثراً حوت كل صفات الحسن والكمال ، فهو كالبدر في جماله، كالغمام في كرمه ليعم فضله على

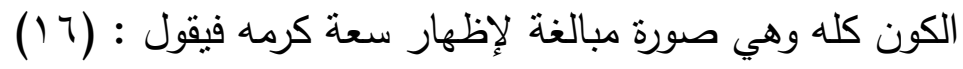

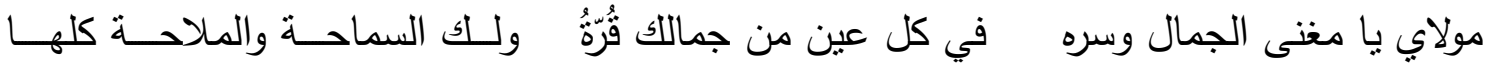

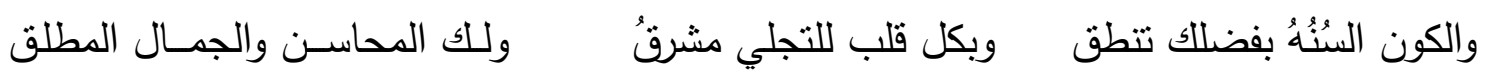
وفي صورة أخرى يظهر قيم جمال الممدوح قائلاً : ( lv) 
يوالى الجميل ويُولى الجزيلا شُفيقاً رفيقاً مهيباً منيباً

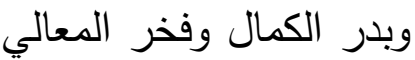
يفيد يبيد بسيب وسيفٍ يُهاب ويُرجى كبرق الغمام إذا قِيست أنملهُ بالغمام

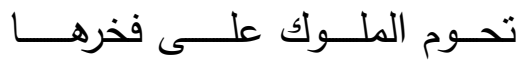
تسيرُ بها الريح مهما سرت مناقب زهرٍ كزهر النجوم ويغنى النزيل ويرعى الدّخيال رحيماً كريماً عطوفاً وصولا نهات وبحر النوال إذا ما استتيلا فيرضي الاله ويرضي الرسُولا يُهاب مُقيناً ويُرجى مُنيلاً وجدنا الغمام حجاماً بخيلا

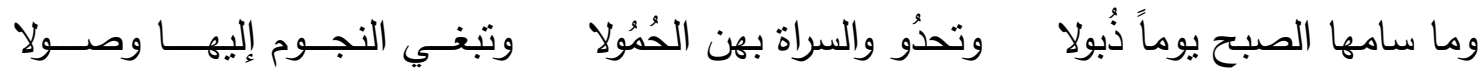
لقد صب الثناعر كل كلمات الفخر والاعجاب في الممدوح ليظهر قيم الجمال لمحبوبه فنوره

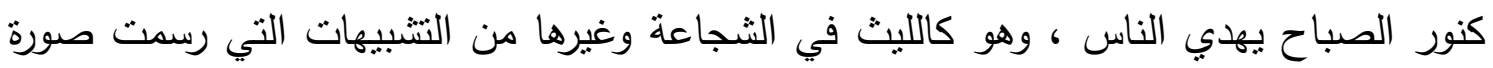

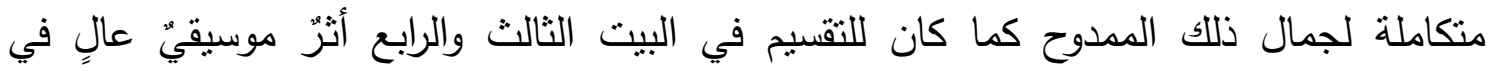
القصيدة أيضاً ويظهر جمال الصورة أيضاً في البيت الخامس عندما يجعل كرمه أكثر من الغمام بل والغمام بخيل قياساً به يزيد كل ذلك مخافة الله وطاعة رسوله الكريم (صلى الله عليه وآله) فمناقبه لا تعد ولا تحصى وعطره كعطر الزهور دون ذبول. ب- جمال الوطن: لا شك أن للوطن وللتربة الأولى مكان في نفوس الناس جميعاً ولاسيما الثعراء، لما يملكوا من موهبة شعرية للتغني بجمال ذللك الوطن فلسانهم ترجمان خاطرهم، فهذا ابن زمرك لاكي

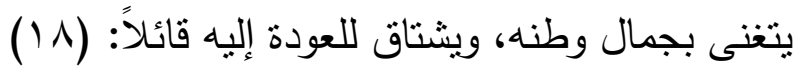
أقمت بشاطئ البحر تبكي بمنله وبالتربة الحمراء ذكرى تجدها وتذكر من غرناطة حسن

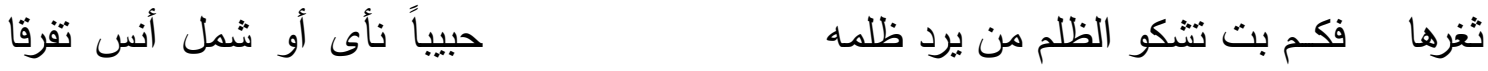

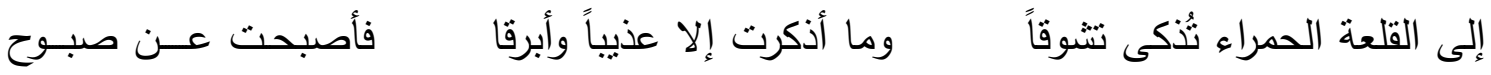

ثم يتذكر جمال ذلك الوطن ومعالمه، والأيام الجميلة، والبركة التي حلت عليهم من الله تعالى بفضل نوحيد أهله، فنشر الهه السكينة والنور عليهم.

ألا تذكر الربع الذي بفنائه منازل حل الوحي في عرصاتها يزور بها الروح الأمين نجيبه

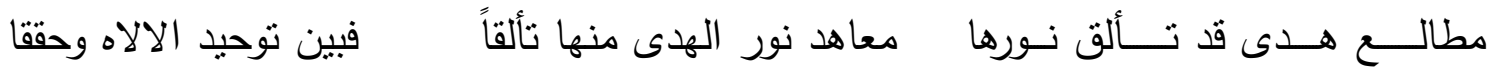

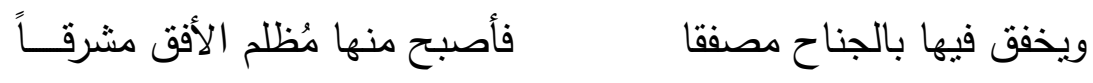

ليجد بعد ذلك مسوغاً لذلك الحب العظيم للوطن، راداً به ملامة من يلمه قائلاً : (9 ) 
فدعن لهذا الحب فهو سجيتي فلو كنت نتكو لا شكوت بمنلها وما بين قلبي أو يُدلّه الهوى

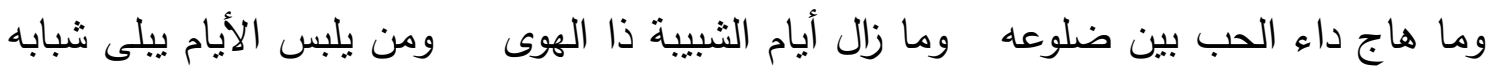

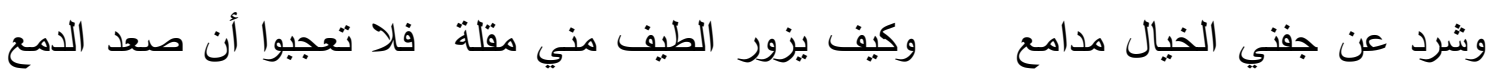

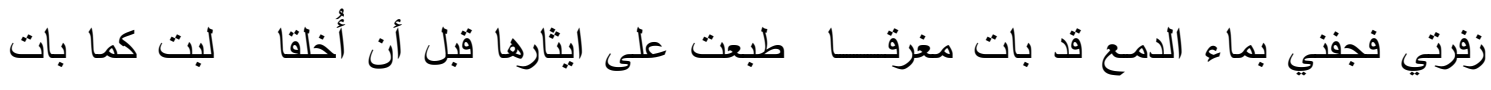

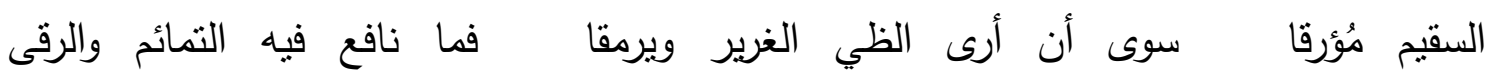

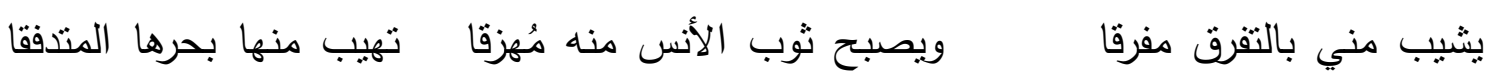

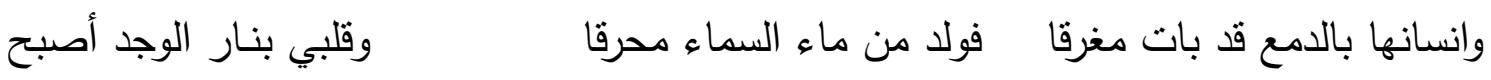
محرقــا بال فتلكك الكلمات العذبة ما هي إلا تعبير عن حبه الكبير لذلك الوطن، فلا ينفع له بعد ذلك تمائم أو رقى ، فقد فارق عينه النوم، وهو بعيد عن وطنه، لكثرة ما يدور في خاطره عنه وشوقه لجماله

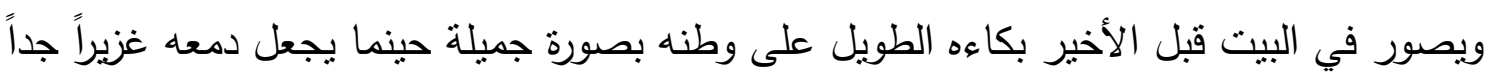
بحيث يولد السماء فتهطل به مجانساً جناساً جميلاً بين (مغرقا ومحرقا) في البيت الأخير . اللغة والأسلوب : الأساليب الانشائية

1- الاستفهام: وهو من الأساليب التي يستعملها الثناعر للتأثثر في المتلقي من خلال تحفيزه عن

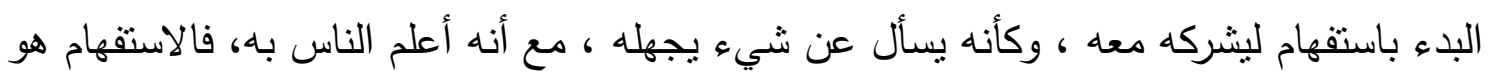

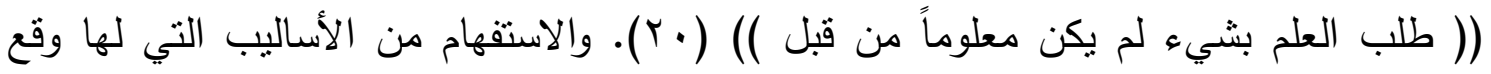

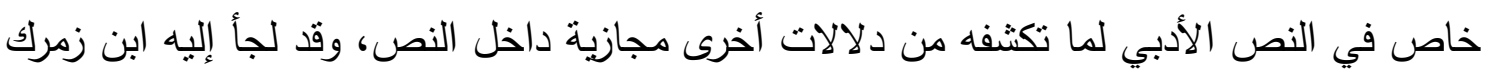

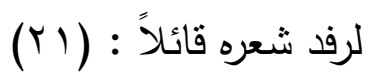

أهـــان فأقصى أم أعز فأكــرم رضيت بمـــا تقضي عــي وتحكـم فقد استعمل حرف الاستفهام (الهمزة)؛ لبيان رضاه عن حكم حبيبه. وقوله مستقهماً بالهمزة أيضاً)

تبـــي عـــاري بالبنفســـج والآس

أروض شبابـــي كم جنينك ياتــعاً وفي مقطوعة أخرى يبدأها بأدوات استفهام عدة ليبرر بها قلق نفسه قائلاً:(r (T)

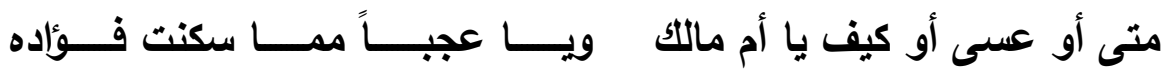

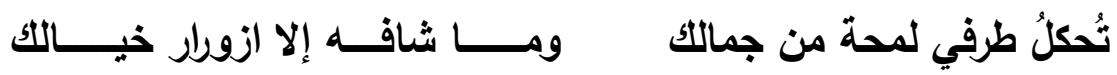


فقد احتوى البيت عدة استقهامات، هي : (متى ، كيف ، من ، ما) وما هذه كلها إلا لبيان صورته النفسية المتحطمة أمام حبيبته.

وينتقل من جمال الحبيبة إلى بيان القيم الجمالية في المدوح، ويمدح شجاعته. (ع ب) أ مضاهياً فلق الصباح بعزمه أ محاسناً شمس النهار بوجهه من منكما يطوي الجهاد وينثر أ مكاثــــراً شهـب السمــــاء أسنــــةًة من منكما بعد الغُرُوب النير من منكمــــــــر الالاه وينصـر

فقد كرر حرف الاستفهام الهمزة مبندئاً بها شطر أبياته الأولى، وكذلك حرف الاستفهام (مَنْ)

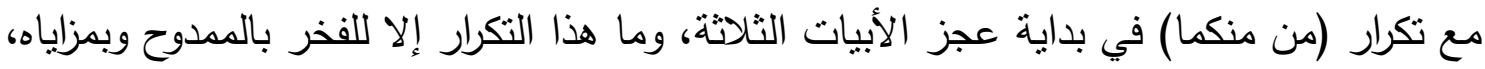

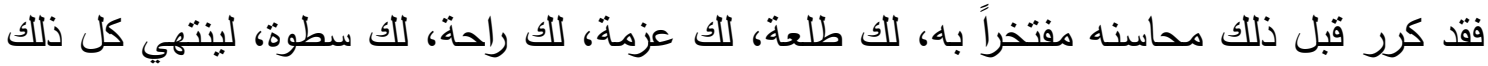
بالنصر المؤكد له كيف لا وقد اجتمعت به كل خصال الثجاعة والكرم من خلال ما اثملت عليه

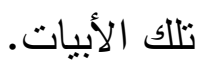

r- النداء: وهو من الأساليب الثعرية التي يلجأ إليها كثير من الثعراء، وهو " طلب الإقبال

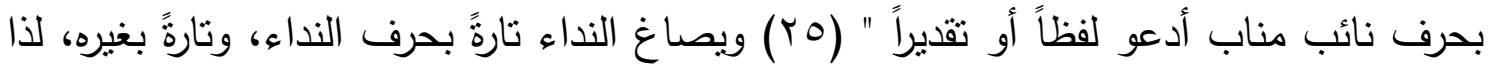

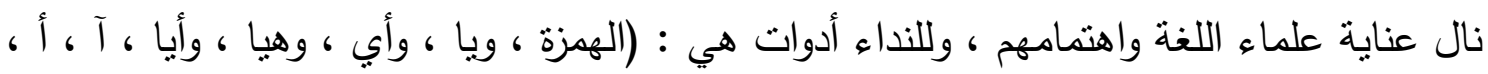

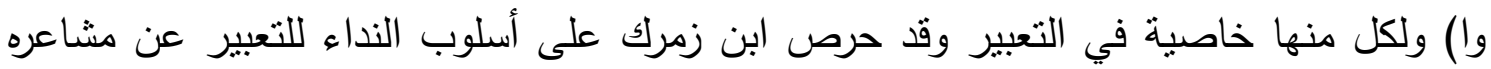

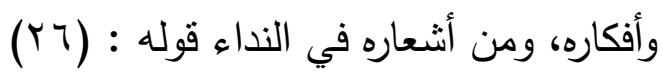

يا من إذا نفحت نواسم حمده يا من إذا جليت محاسن ملكه يـا مـن إذا جليت محاسـن ملكـهـ

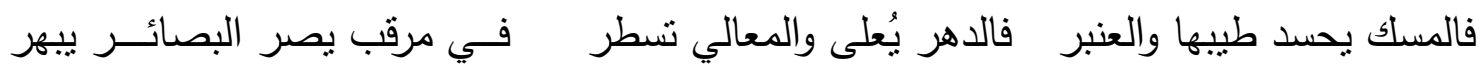
فقد استعمل حرف النداء (با) وهو لنداء القريب والبعيد، فضلاً عن التكرار الملحوظ في المقطوعة، لبيان القيم الجمالية الممدوحة، فقد كرر بداية كل شطر (بامن إذا)، في البيتين الثاني

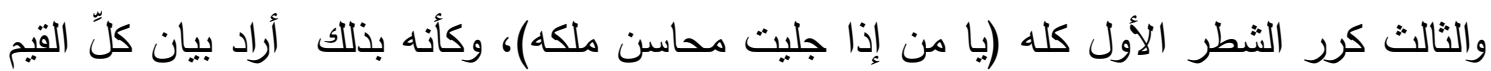
السامية لممدوحه، من كرم ، وشجاعة، وطيبة أصل. يا ظبي أنس وما للظبي طلعته يـا واعــدي وحياتي رهن موعــــده أفديك منه بجهم الوجه خناس روض الرجـاء ذوى من لفحة اليأس 


$$
\text { ويستعمل حرف النداء (يا) في قوله : (rV) }
$$

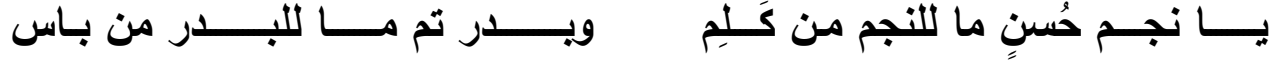
فقد استعمل حرف النداء (يا) مبتدئاً به بداية كل شطر ، معبراً به عن حبه لحبيبته. وقوله أيضاً : (r^)

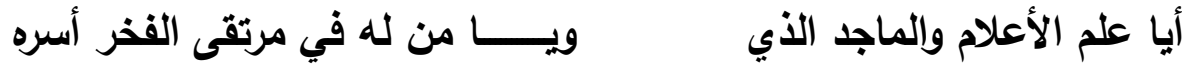

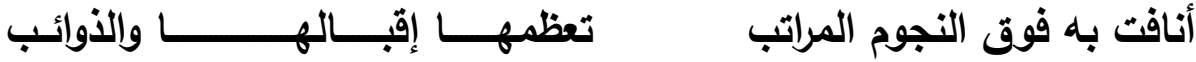

فقد استعمل حرف النداء (أيا) في الثطر الأول من البيت الأول، و (با) في الثطر الأول من

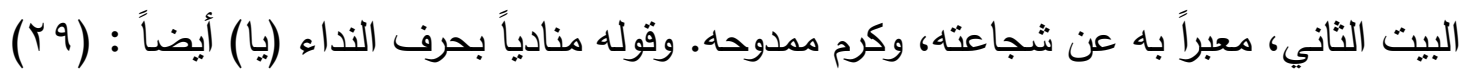

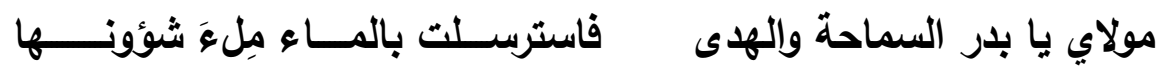

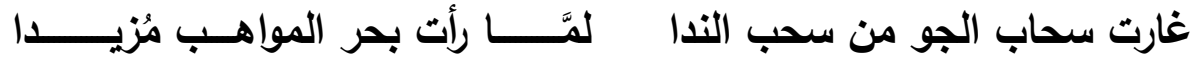

فقد استعمل حرف النداء (با) معبراً به عن كرم الممدوح فقد غارت سحب السماء من جوده

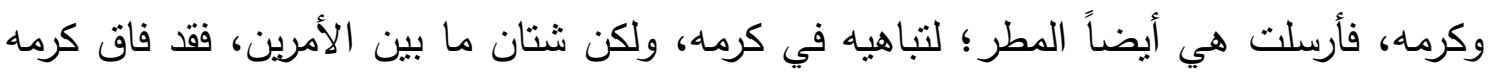

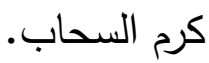

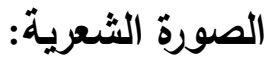

الصورة الثعرية وسيلة تعبيرية لنقل التجربة الثعرية للثاعر، وأجمل ما في الصورة الثعرية التخييل الذي يرتبط بالوعي للإنسان، ويتحفز ذلك التخييل من خلال رسم الثناعر لصورة يريد

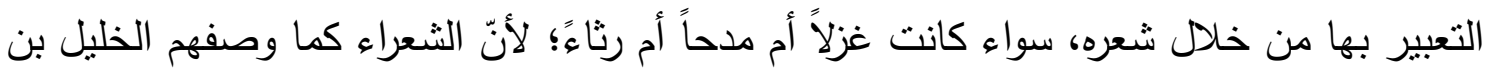

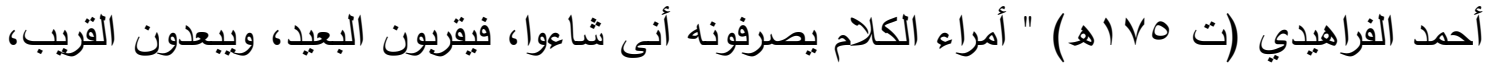
ويحتج بهم، ولا يحتج عليهم، ويصورون الباطل في صورة الحق ، والحق في صورة الباطل " (·ץ). ولقد لجأ ابن زمرك للصورة، فرسم لنا صوراً جميلة من خلال التشبيه والاستعارة، ليبين قدرته الثعرية في خلق علاقات لغوية جديدة بين الكلمات. 
وهي من أكثر الصور التي بستعطلها الثعراء للتعبير عن مكنونات أنفسهم ولترجمة الفكرة التي

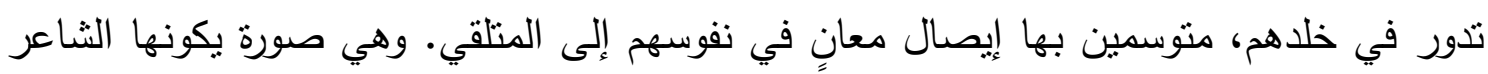

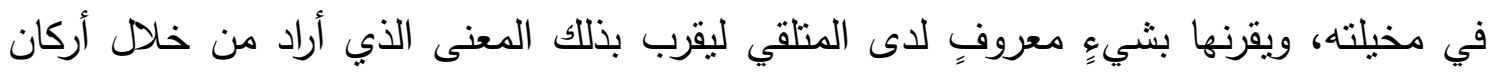

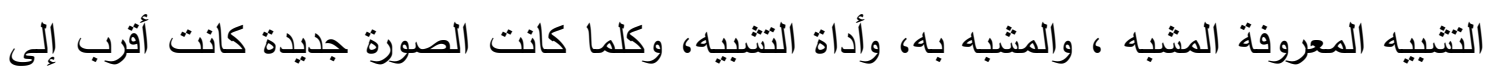

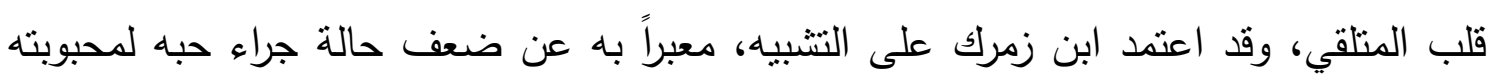

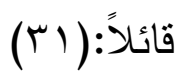

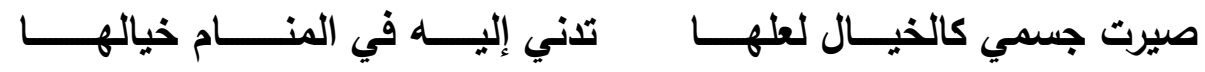

فقد اعتمد ابن زمرك على التشبيه، مستعملاً أداة التشبيه (الكاف) في قوله (كالخيال) راسماً

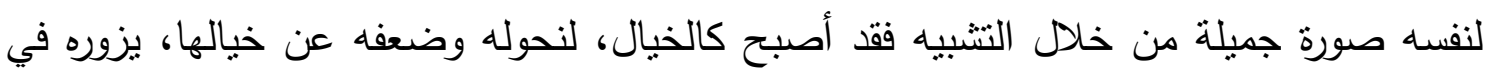
المنام، فيسعده، ويتضح جمال الصورة من خلال ما اعتمده من الجناس بين الخيال الأول، وهو لئه ضعفه، وبقايا جسمه، والخيال الثاني المقصود بهال طيف الحبئية. ويلجأ إلى النتبيه مرة أخرى، ليبين ضعف قلبه قائلاً : (r؟T)

\section{وما عنى غير قلبي من شبيهه كم ليلة أطبقت جفن الظـلام علــى} كريشة في مهب الريح في قلق طيف الخيـال ومـــا جفني بمُنطبـق

فيعبر عن عدم استقراره، وضعفه عندما يشبه قلبه بالريشة في مهب الريح، وهي صورة تعبر

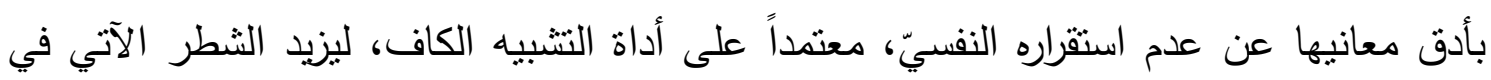

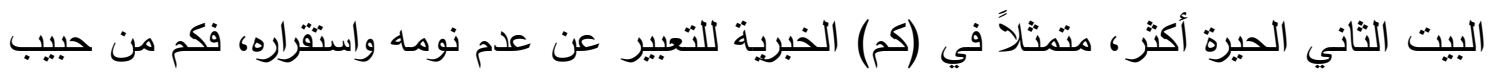
سعد بلقاء حبيبه في المنام إلاّ جفنه لم يطيق ليرى حيبيه. ومن جمال الحبيبة كجمال كرم الممدوح، يرسم ابن زمرك صورة جديدة، معتمداً على البحر في قوله: (rr) (ب)

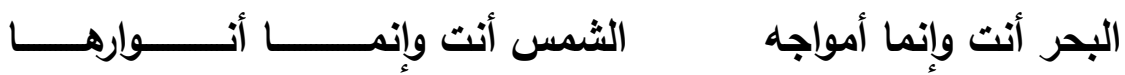 تحيي بزاخر جودها من تُُرق ت تهـي الضيــــــاء وحرها لا يحـــرق}

لقد اعتمد ابن زمرك على الطبيعة، مسخراً أكرم ما في الطبيعة (البحر والثمس)، ليرسم بهما

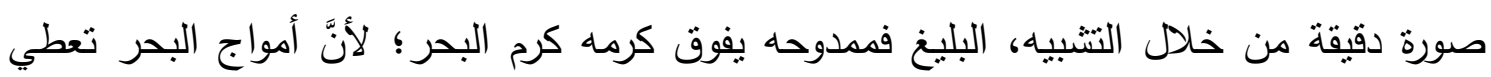

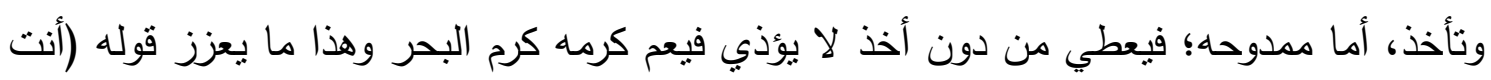


البحر) وتمتد الصورة لتتمل ذلك العطاء عندما يشبهه بالثمس التي تهدي النور ؛ لكنها لا تحرق

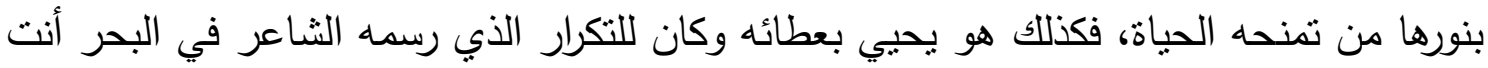

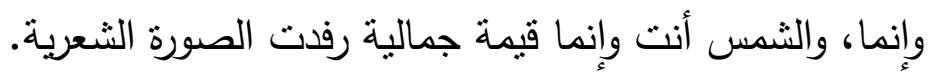

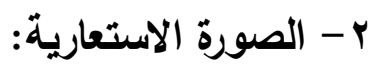

الاستعارة نمط من التشبيه، أو أساسها التشبيه، ولكن أعمق منه، وهي "أكثر اختصاراً أو

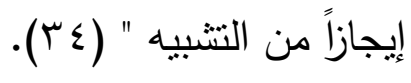

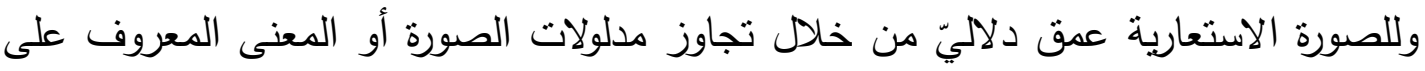

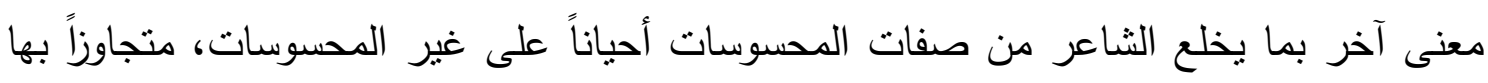

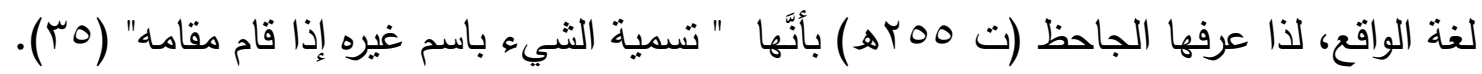
وللاستعارة القدرة على تحريك العقل والبحث والتفتش عن المعنى المراد الذي طرحه الثاعر ولاسيما أن صور ابن زمرك لم تكن جامدة، بل كانت صوراً تتبض بالحياة قائلاً (ج؟):

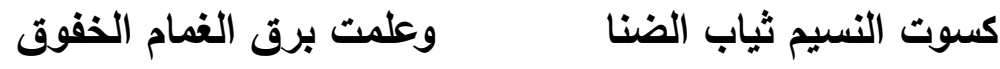

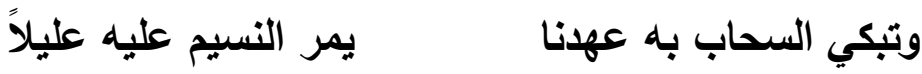

وتهفـو الغصـــــون إليـــــه سكــارى وألبست شمس الأصيل النحولا

فتضحك بالنور روضاً بليلا

وتسحسب للزهــــر فيــــهـ الأبــــــــلا
وعلمت ورق الحمام الهايلا

\section{فيطفي غليلا ويبري عليلا}

لقد رسم ابن زمرك صوراً متعددة معتمداً فيها على الاستعارة من خلال ما أضفاه على النسيم والثمس من صفات الإنسان، لنتاركه همه، وطول سهره، وضعفه في (كسوت النسيم ثياب الضنا) فالنسيم لا يكتسى بثياب، بل، وجعلها ثياب المرض فالنسيم كحالة مريض لفقد حبيبه وشاركتهما الثمس، فألبست النحول أيضاً، وهذه للإنسان استعارها ابن زمرك للطبيعة، ليرسم لنا بهاب النها صورة

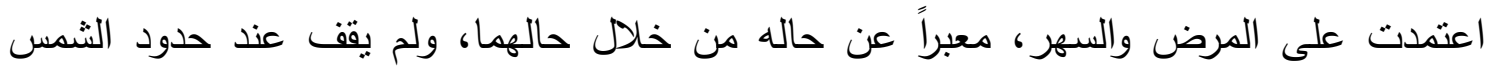
والنسيم، بل تعداهما عندما علم البرق الخفوق، وعلم الحمام الحزن.

لتبكي بعد ذلك السحاب على أياماً مضت، لتجلو عنها تلك الظلمة لتضحك بالنور تلك الروضة

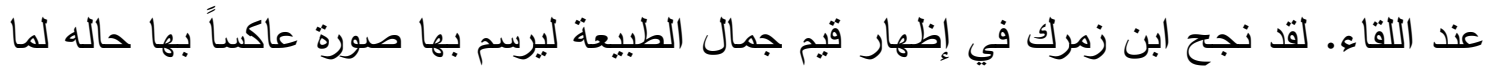


يعانيه من ألم وحزن وضعف من خلال الاستعارات (ثياب الضنا ، ألبست الثمس النحولا ، تبكي

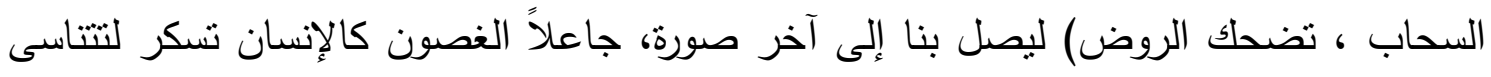

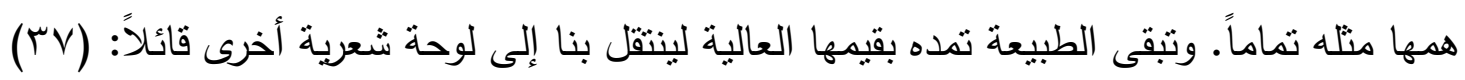

وكــذا الصبا تندى

فبكى بغيث مثل دمعي ساجماً
حتى رسول البرق خان أمانتي لكن وفي لي مُزنهُ من بعده

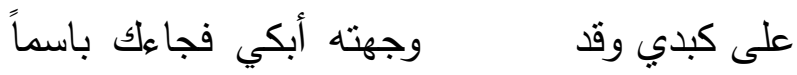
تركت بقلبـــي للصبابــة جاحمــــا

يتضح جمال الصورة عندما يجعل البرق كالرسول الأمين الذي يؤدي الأمانة لكنه للأسف

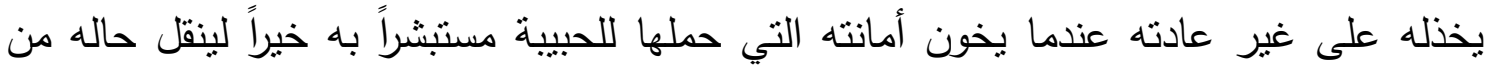

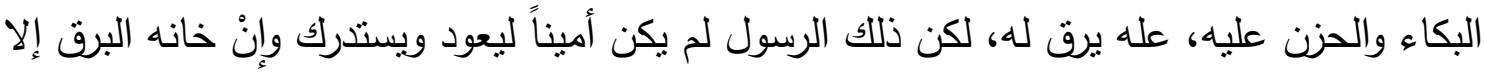

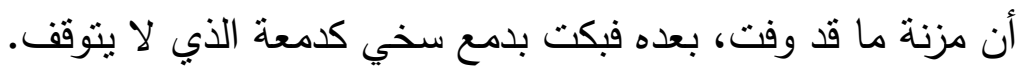
فقد استعار صفات الانسان (الأمانة ، البكاء ، الابتسامة ، الدمع ، الوفاء) وأضفاها على إلى الطبيعة راسماً بها صوراً استعارية عدة.

وتبقى الطبيعة بما تملكه من قيم جمالية، ترفد مخيلته بأجمل الصور ليرسم صورة تظهر قيم

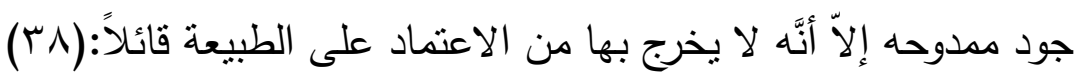
تعلم منك الغيث شيمة جوده وشتان ما بين اليزيدين(ج) في الندى فـــا جــاد إلا

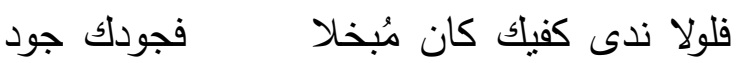

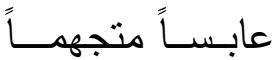

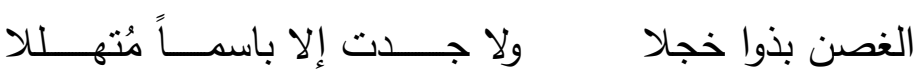
فقد رسم صورة استعارية معتمداً على (عبوس الجود) و (فرحة الجود) جوده، أي مدوحه، مقارناً

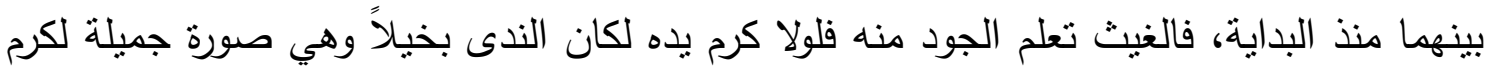
مدوحها، يرتقي بجوده، ويزيد بكرمه من اثتهر في الكرم في البيت الثناني. ץ-الموسيقى: للموسيقى أثر عظيم في النفس ؛ لأنَّها الجرس الذي يبعث الطرب في النفوس لما لها من وقع موسيقى على الأذان ، فتشدد بذلك أزر المعنى ويتسلل صداها إلى قلى لألوب السامعين. وتتضافر الموسيقى الداخلية في شعر الثاعر ابن زمرك لتمنحه إيقاعاً موسيقياً عذباً، متمنلة بالتكرار، والجناس ، والطباق؛ لتعمل مع الصورة على إبراز جمالية البيت الثنعري : 
1- التكرار: وهو من الأساليب التي يلجأ إليها الثشاعر للتأكيد على فكرة ما بداخله وهو من الأساليب البارزة في شعر الثعراء فبالتكرار يبلغ الثشاعر ما يرومه ويتمكن من إيصال المعنى الذي لئي

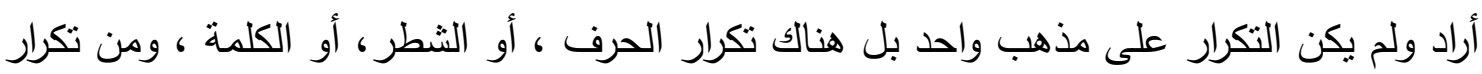

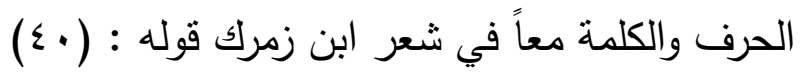

فســرى عن الجســــــم في سقامــه

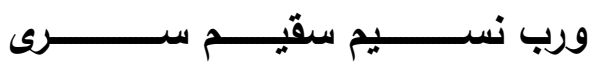

فقد كرر حرف السين (خمس) مرات فضلاً عن تكرار (سقيم) و(سرى) ومن ذلك الفن قوله أيضناً:(

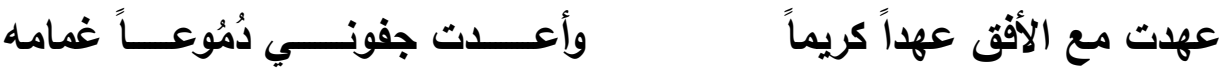 وأعـــــى سئهــــادي عيـون النجوم فيرعى ذمامي وأرعى ذمامه}

حقق التكرار الحاصل في البيتين جمالاً إيحائياً عالٍ من خلال ما تطرق إليه الثناعر، ممّا

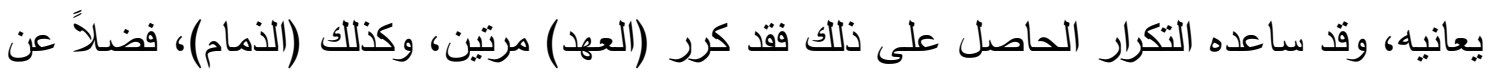

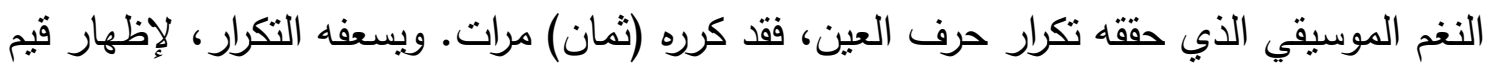

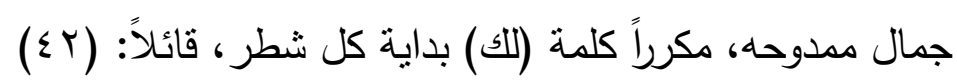
للك طلعة قد أخجلت بدر الدجى للك راحة فضح الغمام سخاؤها للك عزمة نثر الصباح

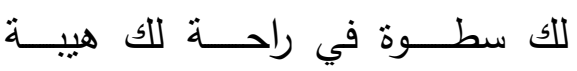
للك فكرة مشكاتها قُُسية لواءها فلذاك سيما النقص فيه تظهر فلذ تجهم وجها إذ تمطر فيها تباتشير

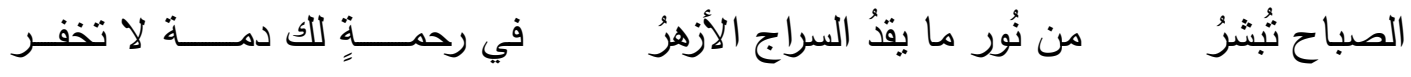
يتضح جمال الصورة التي رسمها في البيت الثاني، فكرمه ككرم السحاب حين تهب الحياة بالمطر

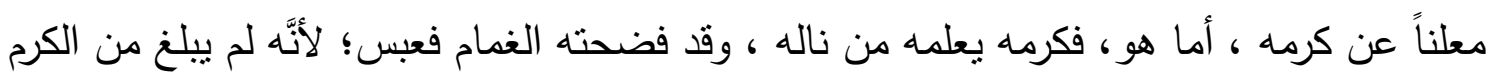
مبلغ الممدوح.

وتبقى قيم جمال الممدوح تتقلب بين التكرار، فيقول مبتدئاً تكراره باستفهام:( ع)

فمن ذا يباري الريح في غلوائها ومن ذا يضاهـي أو يظاهر مشرقاً

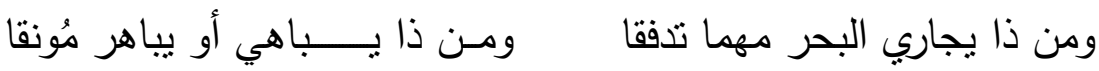




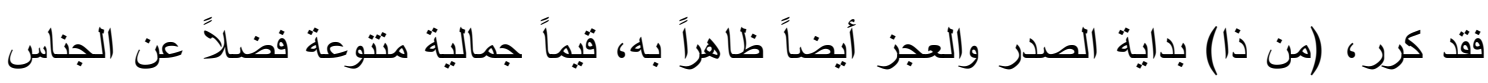
بين (يباري ويجاري) و (يظاهر ويباهر) ومن جمال المدوح ينتقل لقيم جمال الحسية، قائلاً

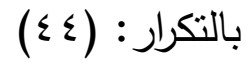

\section{من شجوني رق الأصيل اعتلال من جفوني تهمى الغــام انتحايــاً

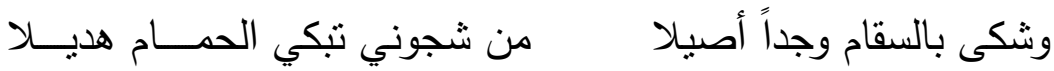

فقد كرر (من شجوني) بداية الثطر الأول، وبداية العجز الأول من البيت الثاني، فضلاً عن تكراره

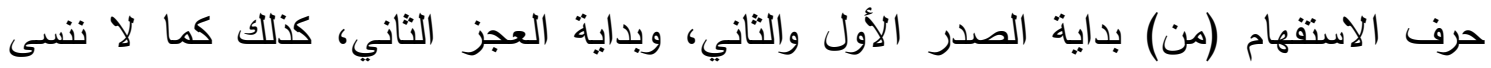
الجناس بين (الأصيل)، أي النسمه و (أصيلاً) أي موجود، وكذللك بين (جفوني) و (ثجوني) والغمام

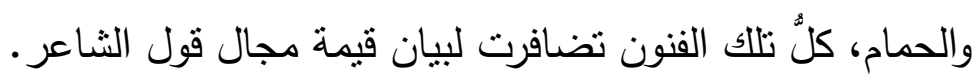

r- الجناس : هو من الفنون البلاغية التي برع فيها الثاعر، والجناس هو أن تتشابه كلمتان في

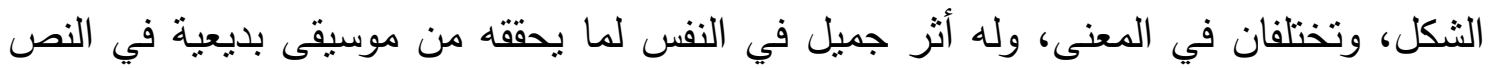

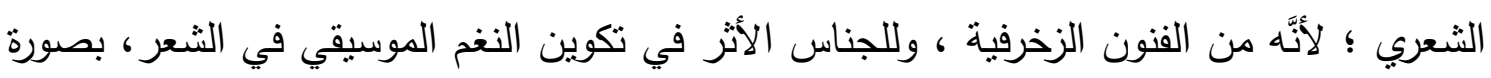

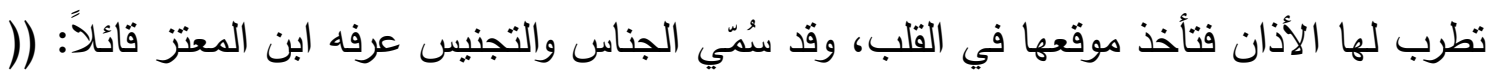

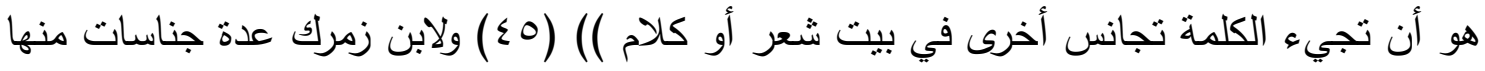
قوله : (

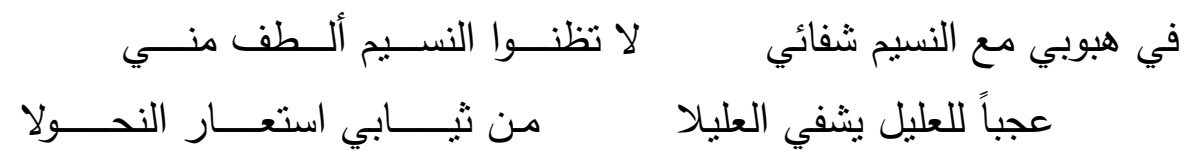

لقد جانس بين (العليل) و (العليلا) والأولى النسيم والثانية العليل، أي المريض، ويظهر ذلك النحول رقة وجمال نفسه، فهو أرق من النسيم، فقد استعار منه النسيم صفات العانشق.

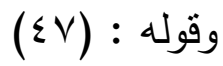

فمن قـبل ما قد خــان قيساً قياسه

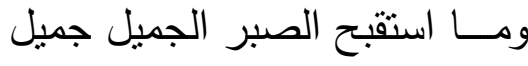

أرى الحب يستهوي النفس رشادها فسيان منه عالم وجهول

فقد جانس بين (الجميل) و(جميل) والأولى بمعنى الصبر الطويل، أما الثانية، فيقصد فيه (جميل بثينة) الثناعر العذري المعروف. 
ثم ينتقل لبيان قيم المدوح قائلاً : (^^)

ســابقاً في الفخار سبـق

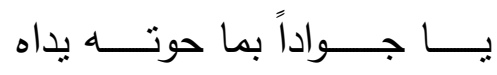

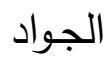

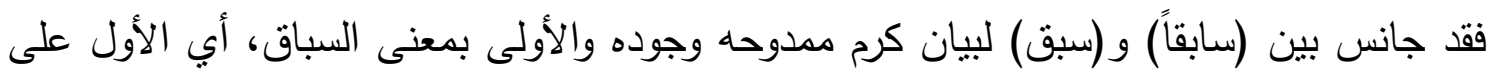

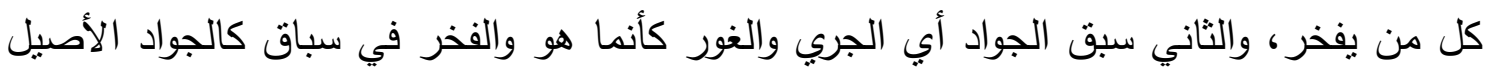

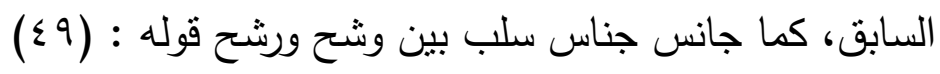
الله

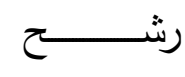

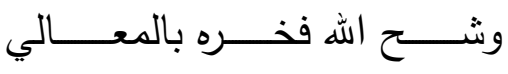
Lاد

ويجانس أيضاً بين (الكأس) و (يأس) جناس سلب في قوله : فليس علــى من يطرد الهم بـأس خليلي طارحني الحديث عن الكأس r- الطباق : من الفنون البلاغية الني لجأ إليها ابن زمرك الطباق ، أو المطابقة، ويسمى أحياناً

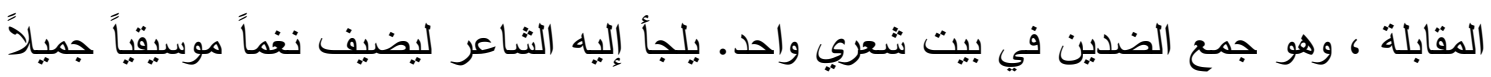

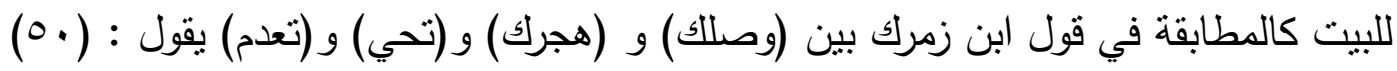

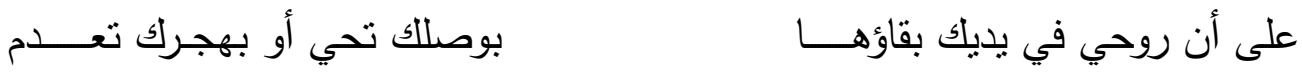
وقوله أيضاً مطابقاً بين (نار وجنة) و (بعد وقرب) و (يشقى وينعم) يقول: (10) وأنت إلــى المشتاق نــــار وجنــــة

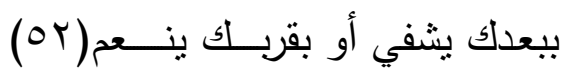
وما زلت أخفي الحب عن كل عاذل * * * وتبدي دموع الصب ما هو يكتهم وكتلك المطابقة بين (تبدي ويكتم) ونلحظ من خلال هذين البيتين القيمة الجمالية العالية التي

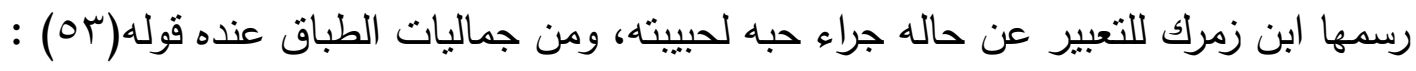




$$
\begin{aligned}
& \text { وكل غني أو فقير فإنه سدلت على الأكوان سجساج منـــــ } \\
& \text { يمد يد المحتاج عند سؤاللكِ }
\end{aligned}
$$

فقد طابق بين (غني وفقير) و (طوعاً وكرهاً) لخدمة جمال الحبيبة التي يقف الكل أمامها سواسية عاجزين.

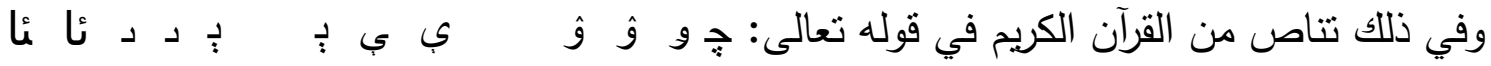

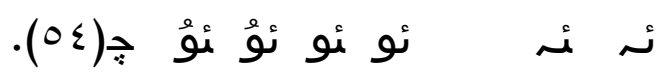

يتضح بعد ذللك أن ابن زمرك قد برع في ذللك الفن لاقتداره الثنعري على ذلك، فمن المعلوم أن لكل شاعر اقتدار في لون ما، ولمنطلبات عصره سيما أنه كان شاعر بلاط وأغلب قصائده في المديح

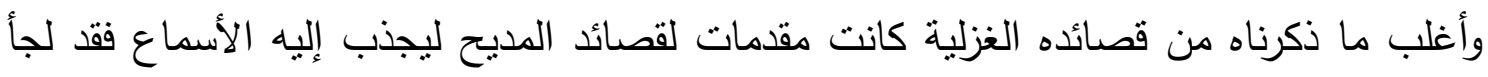

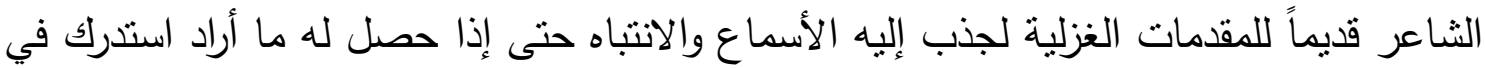

وبعد تللك الرحلة في شعر ابن زمرك وصلنا إلى عدد من النتائج، منها:

1- أهمية الجمال لما له من وقع في النفوس، ولتداول جميع الكتب والمصادر أخباره. r- ياة ابن زمرك المأساوية والتي عزاها المقرى إلى العقاب الالهي.

r- - شهر جمال الحبيبة مساحة من ديوانه، فقد تغنى ابن زمرك بجمالها المادي والمعنوي. ع - إبراز القيم الجمالية النفسية للمدوح من كرم، وشجاعة وطيب أصل، وكثيراً ما شبهه بالغيم والبحر ، بل كثبراً ما فاق سخاؤه الطبيعة.

0- - إبراز القيم الجمالية للوطن وللطبيعة الأندلسية التي أيقظت مواهبهم الثعرية. צ- وفي الأساليب أكثر من استخدام الاستفهام لما له من عدة دلالات يعنيها الثاعر غير الحقيقة، وكذللك اعتمد على النداء.

- - وقد كان للصورة التشبيهية والاستعارية حضور بارز في ديوان ابن زمرك عبر بهما عن أغراض شعره لما لهما من دلالات في نفس المنلقي، معتمداً في أغلبها على الطبيعة. 
^- - كما كان للموسيقى الداخلية المتمثلة في التكرار والجناس والطباق أثراً نفسياً بليغاً من خلال

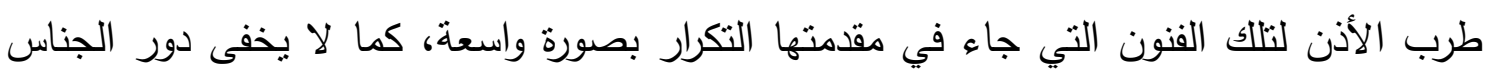

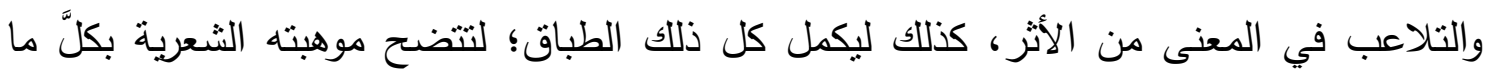
يملك.

\section{الهوامش: - اش}

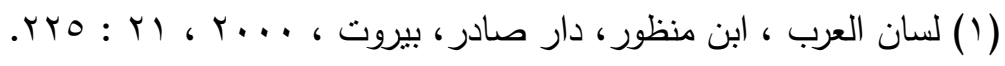

$$
\text { rro: : U S (r) }
$$

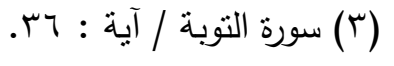

( ) معجم المصطلحات العربية في اللغة والآداب ، مجدي وهبة ، وكامل والمهنس ، مكتبة لبنان ، بيروت ، $.17 V: 19 \vee 9$

$$
\text { (0) أسس الفلسفة ، توفيق الطويل ، مكتبة النهضة المصرية ، طب : 0. ؟؟. }
$$

(7) أساس البلاغة ، العلامة جار اله أبو القاسم محمود بن عمر الزمخثري، مركز تحقيق النزاث ، الهيئة

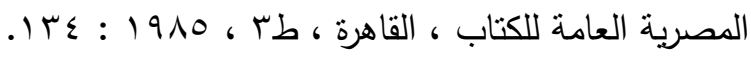

$$
\begin{aligned}
& \text { (Y) لسان العرب ، ץ : Y.r. }
\end{aligned}
$$

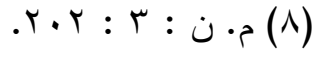

$$
\begin{aligned}
& \text { (9) سورة النحل / الآية : 7. }
\end{aligned}
$$

( • () كثاف اصطلاح الفنون ، التهانوي، تحقيق لطفي عبدالبديع ، مراجعة حسين الخولي ، الهيئة المصرية

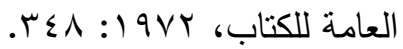
(1) أسس الفلسفة ، د. توفيق الطويل: 110ء.

$$
\text { . }\{\wedge \text { : : (I) }
$$

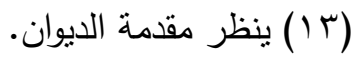

$$
\begin{aligned}
& \text { ( ) (الديوان : ( ) } \\
& \text { (10) الديوان : YNV. } \\
& \text { (ד (1) الديوان : זדז. }
\end{aligned}
$$




$$
\begin{aligned}
& \text { ( الديوان : ( V ) } \\
& \text { (1) (1) الديوان : Vrr. } \\
& \text { (19) }
\end{aligned}
$$

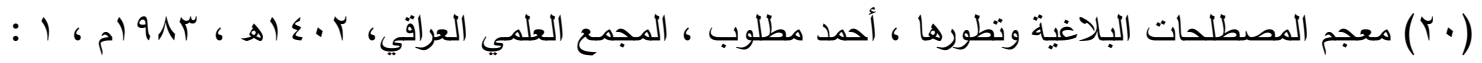

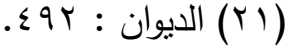

$$
\begin{aligned}
& \text { (Yr) } \\
& \text { (r) } \\
& \text {. }
\end{aligned}
$$

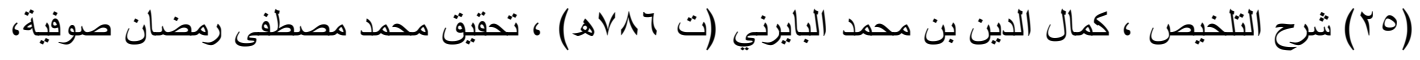

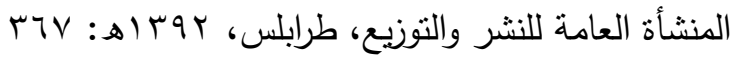

$$
\begin{aligned}
& \text { (דץ) الديوان : ؟ §. }
\end{aligned}
$$

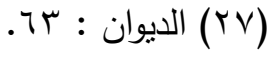

$$
\begin{aligned}
& \text { (YA) } \\
& \text {. } V r: 0 \text { : (rq) }
\end{aligned}
$$

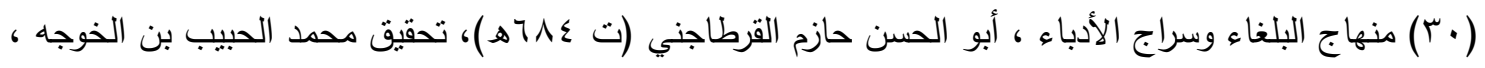

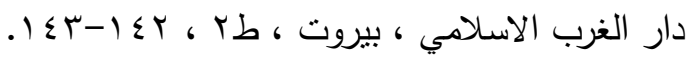

$$
\begin{aligned}
& \text { ( آب) الديوان : } 79 . \\
& \text { (r) الديوان : } \\
& \text { (rT) }
\end{aligned}
$$

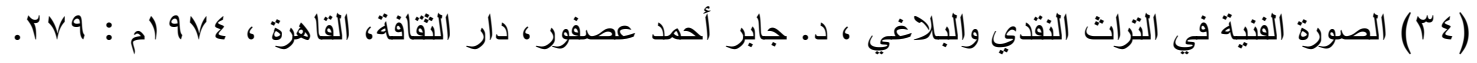

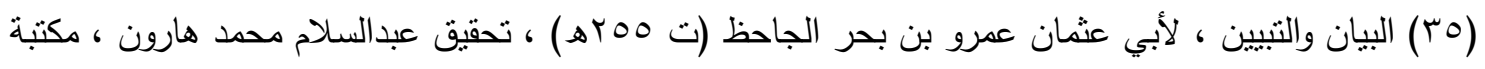

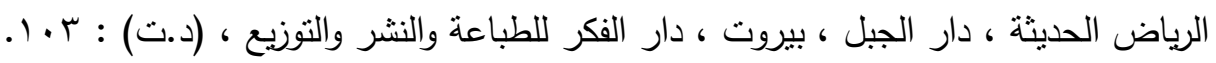




$$
\begin{aligned}
& \text { ) الديوان : I I ا. } \\
& \text { (זی) الديوان : ــ. }
\end{aligned}
$$$$
\text { (\%) هذا البيت مقتبس من البيت: }
$$

يزيد سليم واليزيد بن حاتم

لشتان ما بين اليزيدين في الندى

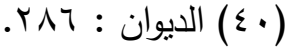

$$
\begin{aligned}
& \text {.rAV: } \\
& \text { (r) الديوان : ـ §. }
\end{aligned}
$$

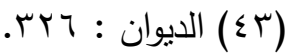

$$
\begin{aligned}
& \text {.ror: }
\end{aligned}
$$

(0) البديع في نقد الثعر ، أسامة بن منقذ (ت ^§ 0هـ) ، تحقيق د. أحمد بدوي د. حامد عبدالحميد ، القاهرة ،

$$
\text { ط1 ، . ro: }
$$

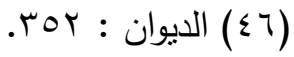$$
\text { .r }
$$$$
\text { . } 9 \text { : الديوان ( }
$$$$
.1 \cdot 9: \dot{0} \text { ن }(\leqslant 9)
$$

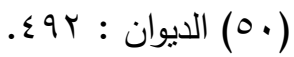$$
\text { .ะ9r: }
$$

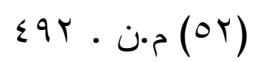$$
\text { (r) }
$$

(ع ان) سورة فصلت / الآية : 11. 


\section{المصادر والمراجع :}

1- أساس البلاغة ، العلامة جار الله أبو القاسم محمود بن عمر الزمخشري، مركز تحقيق التراث ، الهيئة

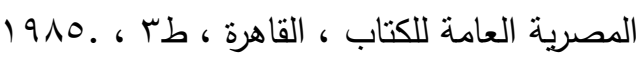

r- أسس الفلسفة ، نوفيق الطويل ، مكتبة النهضة المصرية ، ط.ب؟

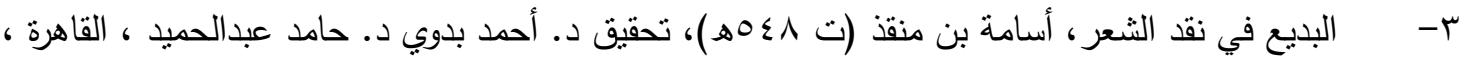
. 197 . 6 1

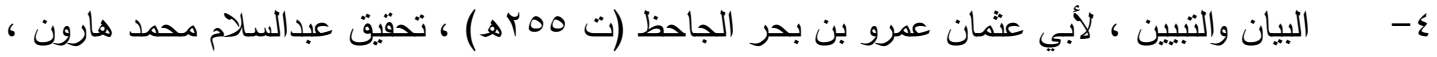
مكتبة الرياض الحديثة ، دار الجبل ، بيروت ، دار الفكر للطباعة والنشر والنوزيع ، (د.ت).

0- - ديوان ابن زمرك الأندلسي ، محمد بن يوسف الصريحي، بالاعتماد على مخطوط فريد عنوانه " البقية

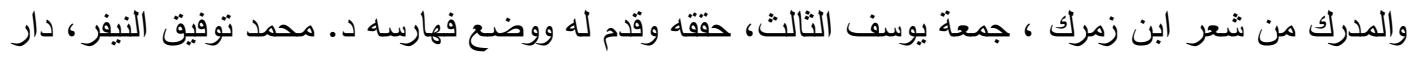
الغرب الإسلامي ، طا ، . 199V

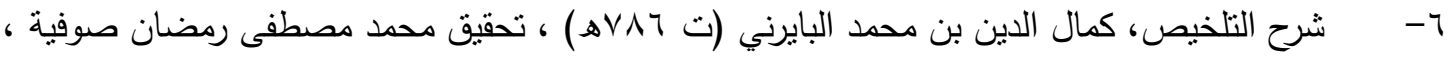

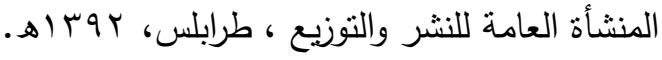

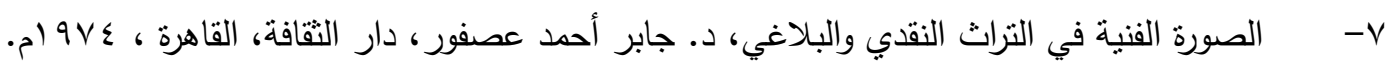

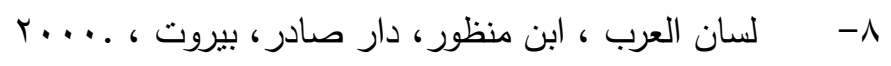

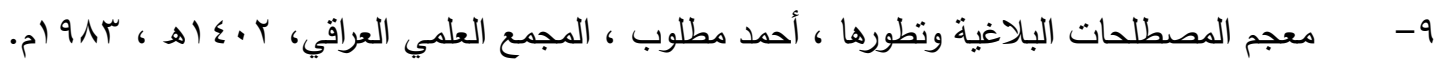

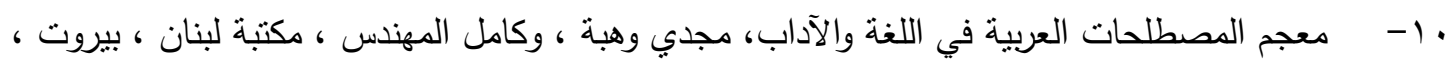
$19 \times 9$.

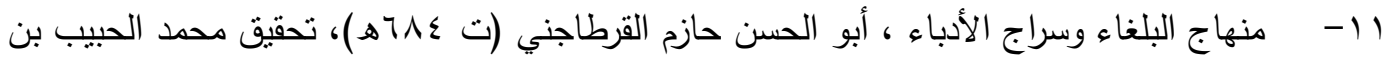
الخوجه ، دار الغرب الاسلامي ، بيروت ، طبه 


\title{
Poetic values in the poetry Zmrk \\ Technical study \\ M. Dr. Afrah Ali Osman \\ University of Baghdad / College of Languages
}

\begin{abstract}
:
God has printed exalted the human soul to love beauty, praising him wherever he found it a humanitarian instinct when all human beings, Vttrb ear to hear all the beautiful also adores heart all beautiful and out of this was our research titled ((aesthetic values in the hair ibn zamrak)) technical study, This has required the division of research on two topics, their progress in preparation divided on two paragraphs, was one of them said in a statement the concept of value and beauty, while the other; was simple lighting for the life ibn zamrak since they must know the lines about his life before starting to read his poetry, the first section; was in a statement aesthetic values in his office divided on the first three points in the beauty of the beloved, and the second in the beauty of acclaimed or the same acclaimed, and the third in the beauty of the homeland, and came second part, the technical study divided on three points also, was the first in the study of some of the hair styles, including the question, and the appeal, and the second in the poetic image, Frdhana Alastarah simulations and some poems in the picture, and the last was in the inner musical study of his hair, divided by the repetition, alliteration, and counterpoint, followed by all of this conclusion included the most important results, then a list of sources and references.
\end{abstract}

